\title{
Performance of Released Soybean Varieties at Jimma, South Western Ethiopia
}

\author{
Yechalew Sileshi $^{13} \quad$ Masresha Yirga $^{1} \quad$ Mesfin H/Mariam $^{1} \quad$ Behailu Atero \\ 1.Ethiopian Institutes of Agricultural Research, Jimma Agricultural Research \\ 3.National lowland oil crops research coordinator, Soybean innovation lab project coordinator and Pulse, oil and \\ fiber crops research Representative at Jimma Agricultural research center \\ P.O. Box, 192, Jimma, Ethiopia
}

\begin{abstract}
Soybean is becoming economical important oil crop in Ethiopia. The process of plant growth and development is important to the successful adaptation of a species to its geographic and climatic environment. Evaluating the adaptability of released soybean varieties in diverse agro ecology is important for efficient use of nationally released varieties in their area of adaptation and thereby increases production and productivity of soybean in the country. The trial was conducted with 19 released soybean varieties in the year 2015 and 2016 main cropping season at Jimma, South Western parts of Ethiopia. The experimental design used was RCBD with three replications. The parameters collected include; days to flowering, days to maturity ,number of pod per plant, number of seed per plant ,hundred seed weight, rust ,common bacterial blight, lodging score and grain yield. The statistical analysis showed significant difference at $(\mathrm{P}<0.05)$ among the varieties for some parameters. The interactions of year by varieties showed significant differences for all of the traits except hundred seed weight. Mean grain yield ranged from $1.16 \mathrm{t} / \mathrm{ha}$ to $4.2 \mathrm{t} / \mathrm{ha}$. The three high yielding varieties were Nyala $(4.19 \mathrm{t} / \mathrm{ha})$, Cocker-240 (3.9 t/ ha) and Williams (3.7 t/ ha). The above mentioned three varieties are recommended for south western Ethiopia.
\end{abstract}

Keywords: Potential yield, released, Recommend

DOI: $10.7176 / \mathrm{JBAH} / 10-4-02$

Publication date: February $29^{\text {th }} 2020$

\section{INTRODUCTION}

The cultivated soybean (Glycine max) is self-fertilized crop and it was derived from China from wild type (Dupare et al, 2008). It is a medium-altitude crop and is well adapted to areas located in altitudes ranging from 1300 to $1800 \mathrm{~m}$ and receiving rainfall of 900 to $1300 \mathrm{~mm}$ (Hammer and Haraldson, 1975). It is one of the versatile crops throughout the world. It a good sources of protein content $(40 \%)$ for most developing countries faced with extensive malnutrition and food insecurity, high oil content (20\%), best ingredient for industrial food complexes (Singh et al., 2008). the crop is known to improve and amend soil properties through nitrogen fixation and enhanced moisture retention (Graham and Vance, 2003). Moreover, through soybean with cereal crop rotation programmers the lifecycles of pests and diseases can be break (Waymark, 1997).

World share of soybean production in sub Saharan countries is very low. However, soybean production and productivity in sub Saharan Africa counter indicates increasing trends in the past ten year and expected to increase in the future both in production and productivity (USDA, 2017). In Ethiopia soybean has a total of $38,166.04$ ha of land were covered and 81234655 quintals of production (CSA, 2016). The demand of soybean is increasing from time to time. Currently soybean is one of the focus subsectors supported by government and nongovernmental organization.

Adaptation of Soybean in collaboration with the international soybean research institute was started in South Western parts of Ethiopia in 1950s. South Western parts of Ethiopia had immense potential for soybean production including Jimma, Buno Bedele and Ilu-Ababora zones. Even though this part has potential for soybean production there is huge gape between actual and potential productivity. Farmers in the study area had access to only two improved soybean varieties Viz Clarck-63k, AFGAT hence evaluating the performance of the released soybean varieties has importance to get alternative varieties. To date a total of 26 soybean varieties were released in Ethiopia for different agro ecology for production by different research center (MoARD, 2017). However the performance of the released varieties were not evaluated in the past in South Western part of Ethiopia, therefore the present study was conducted to test the performance of released soybean varieties at Jimma and surrounding areas and recommend adoptable varieties for production.

\section{MATERIALS AND METHODS}

\subsection{The Study Area}

The study was conducted at Jimma Agricultural Research Centers in Ethiopia. Jimma agricultural research centers are located in Oromia region, of South Western Ethiopia. Jimma agricultural research center is located at $12 \mathrm{~km}$ distance from Jimma town $\left(1,754\right.$ m.a.s.1, $\left.7^{0} 40^{\prime} \mathrm{N} 36^{0} 47^{\prime} \mathrm{E}\right)$. The place has a mean maximum and minimum 
temperature of 26.3 and $11.6^{\circ} \mathrm{C}$ respectively with mean annual rainfall of $1,572 \mathrm{~mm}$.

\subsection{Experimental Treatments and Design}

A total of 19 released soybean varieties in Ethiopia (Table 1) were evaluated in randomized completed block design with three replications. The experiment was planted in 4 rows plot of $4 \mathrm{~m}$ length. The spacing used was $60 \mathrm{~cm}$ between rows and $5 \mathrm{~cm}$ between plants. The seed was drilled during planting and later thinned at $5 \mathrm{~cm}$ spacing. Land preparation was made using disc plough for first and second plough and was letter pulverized using oxen driven local plough. 100kg DAP fertilizer (46\% P2O5 and 18\% N) were applied during planting.3-4 hand weeding were practiced to control weeds. Harvesting and threshing is made manually.

Table1.Description of the soybean varieties, maturity type, altitude, year of release and ecology of adaptation soybean varieties used for the study

\begin{tabular}{|r|l|l|l|l|}
\hline \multicolumn{1}{|c|}{$\mathrm{N}^{\mathrm{N}}$} & Variety & $\begin{array}{l}\text { Maturity } \\
\text { Type }\end{array}$ & $\begin{array}{l}\text { Altitude } \\
\text { (m.a.s.l.) }\end{array}$ & $\begin{array}{l}\text { Year of Release/ } \\
\text { Register }\end{array}$ \\
\hline 1. & Gizo(TGX-1885-33F) & Medium & $520-1800$ & 2010 \\
\hline 2. & Gishama(PR-143-(26)) & Medium & $520-1800$ & 2010 \\
\hline 3. & BOSHE( IAC-13-1) & Medium & $1200-1900$ & 2008 \\
\hline 4. & AFGAT & Medium & $1200-1900$ & 2007 \\
\hline 5. & Awassa-95(G 2261) & Early & $520-1800$ & 2005 \\
\hline 6. & AFGAT(TGX-1892-10F) & Medium & $750-1800$ & 2007 \\
\hline 7. & Nyala & Medium & $1200-1800$ & 2014 \\
\hline 8. & Davis & Medium & $1000-1700$ & $1981 / 2$ \\
\hline 9. & NOVA & Early & $1200-1700$ & 2012 \\
\hline 10. & Wello(TGX-1895-33F) & Medium & $520-1800$ & 2012 \\
\hline 11. & Belessa-95(PR-149) & Late & $520-1800$ & 2003 \\
\hline 12. & Wegayen(TGX-1998-29F) & Late & $520-1800$ & 2010 \\
\hline 13. & Clark 63k(Lincoln 2) $\times$ Richland) & Medium & $100-1700$ & $1981 / 2$ \\
\hline 14. & Coker -240 & Medium & $700-1700$ & $1981 / 2$ \\
\hline 15. & Williams & Early & $1000-1700$ & 1981 \\
\hline 16. & Jalale(AGS-2017) & Medium & $1300-1850$ & 2003 \\
\hline 17. & Crowford(Corsoy $\times$ Lee 68) & Early & $700-1700$ & 1981 \\
\hline 18. & Gazale & Early & $800-1700$ & 2015 \\
\hline 19. & Hawasa-04(AGS-7-1) & Medium & NA & 2012 \\
\hline
\end{tabular}

Source: MOANR (2016), NA=Not available

\subsection{Data Collection}

Data were collected both at plot and plant basis. Days to flowering, days to maturity and hundred seed weight, disease severity and yield were collected on plot base. Five plants from the central rows were randomly selected for data collection on plant basis and the averages of the five plants in each experimental plot were used for statistical analysis for traits such as plant height, number of pods/plant and number of seeds/plant.

\subsection{Data Analysis}

The collected data were subjected to Analysis of variance using SAS Software after testing the ANOVA assumptions and treatment means were separated with the Least Significant Difference (LSD) at 5\% probability level.

\section{RESULTS AND DISCUSSION}

The combined analysis of variance across the two years was presented in table 2 . The mean squares due to varieties revealed highly significant $(\mathrm{P} \leq 0.01)$ differences for all of the studied traits. Similarly, the interactions (year $\mathrm{x}$ varieties) showed significant differences for all of the traits except hundred seed weight.

Based on the combined data over the two year wide ranges between the minimum and maximal mean values were observed table 3 . In the present study out of the total tested released soybean varieties eleven varieties shows plant height below the mean value (100.3). The tallest plant height was recorded from Gozela (179.67) and the shortest from Nova (48.93).

Days to $50 \%$ flowering of the genotype Nova was the earliest (41 days); while genotype Gishama showed the latest for flowering ( 85.83 days), days to maturity ranged from 118 for the variety Nova- 166 days for the variety Gizela .with mean value of 144 day to maturity. Similar trends of variability in phonology were also reported in soybean i.e., 30 to 57 days to $50 \%$ flowering, and a range of 79 to 101 days to maturity (Singh et al., 1996). Similarly, differences in days to maturity in different genotypes were reported (Adiyata et al. 2011). 
The tested soybean varieties from this trial shows high variation for days to maturity that means soybean variety classified as medium in northern parts of the countries too late to mature in the study area for example. A soybean variety Gishama released in 2010 and classified as a medium maturing variety by Pawe research center released in Northern part of the country; which is expected to mature from 120-150days after planting however, it matured in 165 days after planting at Jimma. This variety is in late maturity group at Jimma. Further maturity group classification is necessary for different soybean growing regions of the country.

The maximum number of pod per plant was observed on the varieties Gizo (70.0) and the minimum from varieties Nyala (35) with a mean value of 52.3. The result is comparable to the one reported by Shankar (2014), who reported that pod per plant ranged from 19.20 to 53.93 with a general mean of 28.82 pods per plant AFGAT showed the largest number of seed per plant (129.1), while varieties Nyala showed the lowest number of seed per plant (72.6). The maximum hundred seed weight was recorded from the variety Nyala $(21,33 \mathrm{~g})$, while the minimum from the varieties Gishama $(11.3 \mathrm{~g})$. Out of the total tested released soybean variety twelve varieties give more than $25 \mathrm{q} / \mathrm{ha}$. Variety Nyala highest yielder as compared to the other which give $4.2 \mathrm{t} / \mathrm{ha}$ and the lowest yielding varieties was TGX-1332644 (1.16 t/ha).

Table 2. Mean square of combined analysis for soybean variety adaptation trial over year at Jimma

\begin{tabular}{|c|c|c|c|c|c|c|c|c|c|c|c|}
\hline $\begin{array}{l}\text { Source } \\
\text { variation }\end{array}$ & $\mathrm{DF}$ & $\mathrm{PH}(\mathrm{cm})$ & DTF & DTM & NOP & NOS & HSW & $\begin{array}{l}\text { Yield(t ha } \\
\text { 1) }\end{array}$ & Rust & $\mathrm{CBB}$ & LG \\
\hline Variety & 18 & $5096.7 * *$ & $577.3 * *$ & $1450.24 * *$ & $533.56 * *$ & $1304.26^{* *}$ & $58.44 * *$ & $445.07 * *$ & $1.78 * *$ & $1.39 * *$ & $13.11 * *$ \\
\hline Year & 1 & $325.03 * *$ & $0.116^{* *}$ & $640.39 * *$ & $1549.87 * *$ & $13476.1^{* * *}$ & $0.88 * *$ & $4042.12 * *$ & $19.74 * *$ & $1.14 * *$ & $0.80 * *$ \\
\hline $\begin{array}{l}\text { year* } \\
\text { Variety }\end{array}$ & 18 & $1190.83 * *$ & $34.5^{* *}$ & $120.15^{* *}$ & $408.52 * *$ & $2178.3 * *$ & $0.07 \mathrm{~ns}$ & $258.05 * *$ & $1.62 * *$ & $0.53 * *$ & $0,41 * *$ \\
\hline MSE & 73 & 877.8 & 2.76 & 32.2 & 204.5 & 596.57 & 2.65 & 48.8 & 0.85 & 0.18 & 0.29 \\
\hline
\end{tabular}

Table 3. Combined mean yield and other parameters of Soybean variety adaptation trial over two year at Jimma

\begin{tabular}{|c|c|c|c|c|c|c|c|c|c|c|c|}
\hline $\begin{array}{l}\text { Variety } \\
\text { name }\end{array}$ & $\mathrm{PH}(\mathrm{cm})$ & $\mathrm{DF}$ (days) & DM(Days) & NOP & NOS & HSW & $\begin{array}{l}\text { Rust } \\
(1-9)\end{array}$ & $\mathrm{BB}$ & $\begin{array}{l}\mathrm{LG}(1- \\
5)\end{array}$ & $\begin{array}{l}\text { Yield } \\
\text { t/ha }\end{array}$ & $\begin{array}{l}\text { Rank } \\
\text { based on } \\
\text { yield }\end{array}$ \\
\hline Nyala & 88.30 & 61.00 & 133.50 & 35.27 & 72.60 & 21.33 & 4.08 & 2.92 & 1.00 & 4.19 & 1. \\
\hline Cocker-240 & 89.97 & 63.83 & 135.17 & 45.07 & 79.33 & 18.23 & 4.25 & 2.50 & 1.00 & 3.91 & 2. \\
\hline Williams & 75.00 & 54.00 & 123.33 & 43.13 & 97.90 & 16.83 & 3.83 & 2.50 & 1.17 & 3.69 & 3. \\
\hline AFGAT & 121.73 & 69.33 & 153.50 & 66.50 & 129.10 & 14.17 & 3.50 & 2.00 & 4.83 & 3.25 & 4. \\
\hline Awassa-95 & 77.87 & 63.50 & 134.00 & 56.70 & 94.50 & 17.87 & 4.17 & 2.75 & 3.17 & 3.09 & 5. \\
\hline Crawoford & 78.54 & 60.05 & 134.17 & 47.66 & 80.00 & 20.17 & 3.21 & 2.67 & 1.62 & 3.03 & 6. \\
\hline Clark-63k & 89.53 & 64.50 & 140.50 & 52.27 & 92.37 & 18.47 & 3.83 & 2.50 & 1.83 & 2.96 & 7. \\
\hline Davis & 68.90 & 63.33 & 134.33 & 47.57 & 88.80 & 18.43 & 4.17 & 3.00 & 1.92 & 2.77 & 8. \\
\hline AGS-7-1 & 90.83 & 66.50 & 141.50 & 50.40 & 92.13 & 17.83 & 4.08 & 2.50 & 4.50 & 2.72 & 9. \\
\hline Jalale & 78.13 & 62.00 & 131.83 & 61.33 & 102.70 & 18.63 & 3.67 & 2.50 & 2.83 & 2.63 & 10. \\
\hline BOSHE & 85.60 & 68.67 & 136.83 & 57.30 & 88.50 & 11.40 & 3.50 & 2.83 & 4.00 & 2.54 & 11. \\
\hline Gizo & 120.10 & 71.83 & 160.83 & 70.07 & 112.17 & 13.20 & 2.75 & 1.83 & 4.52 & 2.52 & 12. \\
\hline Nova & 48.93 & 41.83 & 118.00 & 45.37 & 81.97 & 15.43 & 2.67 & 1.83 & 1.33 & 2.18 & 13. \\
\hline Belsea-95 & 130.60 & 80.00 & 160.00 & 62.30 & 107.30 & 14.30 & 3.00 & 2.08 & 4.17 & 2.07 & 14. \\
\hline Wello & 104.50 & 70.67 & 159.83 & 65.67 & 117.00 & 11.67 & 3.00 & 1.42 & 4.33 & 1.76 & 15. \\
\hline WEGAYEN & 109.50 & 75.50 & 159.50 & 46.50 & 83.30 & 16.30 & 3.67 & 2.17 & 4.50 & 1.67 & 16. \\
\hline Gazale & 122.37 & 76.67 & 166.00 & 46.07 & 76.33 & 11.73 & 3.00 & 1.67 & 4.50 & 1.64 & 17. \\
\hline Gishama & 118.97 & 85.83 & 165.67 & 50.83 & 90.57 & 11.33 & 2.67 & 1.50 & 4.75 & 1.22 & 18. \\
\hline $\begin{array}{l}\text { Tgx- } \\
1332644\end{array}$ & 179.67 & 74.33 & 166.83 & 42.97 & 84.70 & 13.13 & 3.08 & 1.92 & 4.50 & 1.16 & 19. \\
\hline Min & 48.93 & 41.83 & 118.00 & 35.27 & 72.60 & 11.33 & 2.67 & 1.42 & 1.00 & 1.16 & \\
\hline Max & 179.67 & 85.83 & 166.83 & 70.07 & 129.10 & 21.33 & 4.25 & 3.00 & 4.83 & 4.19 & \\
\hline Mean & 100.36 & 66.72 & 144.77 & 52.30 & 93.95 & 15.86 & 3.48 & 2.26 & 3.16 & 2.59 & \\
\hline LSD $(5 \%)$ & 11.1 & 0.6 & 2.1 & 5.4 & 9.2 & & 0.4 & 0.15 & 1.1 & 0.29 & \\
\hline $\mathrm{CV} \%$ & 29.92 & 2.47 & 3.91 & 27.3 & 26.2 & 10.33 & 27.22 & 26.52 & 18.79 & 1.71 & \\
\hline
\end{tabular}

Remark $=* *=$ significant at 0.01 probability level, $*=$ significant 0.05 probability level, $\mathrm{DF}=\mathrm{Degree}$ of freedom $\mathrm{PH}=\mathrm{Plant}$ height $(\mathrm{cm}) ; \mathrm{NOP}=$ number of pods/plant; $\mathrm{NOS}=$ number of seeds/plant; HSW= Hundred seed weight; $\mathrm{CBB}=$ Common bacterial blight; $\mathrm{LG}=$ logging

\section{CONCLUSION}

In the last 2 decades or more clarck $63 \mathrm{~K}$ were the dominant soybean variety grown in Jimma,Buno Bedele and Illuababora zones of South western Ethiopia. In the study made for two year with released varieties, Nyala (4.2t/ha), Coker 240(3.91t/ha) and Williams (3.6t/ha) were found the three high yielding varieties based on 2 years mean. These varieties are recommended for Jimma and similar areas in south western Ethiopia as alternative varieties to clarck and Afgat. Among the recommended varieties; Nyala and Cocker-240 has 
attractive seed luster, not susceptible to lodging and good seed size. Therefore, in the future it is essential to demonstrate the three varieties to farmer for production.

\section{ACKNOWLEDGEMENTS}

The authors would like to thank, Ethiopian institute of agricultural Research (EIAR) for the financial support.

\section{REFERENCES}

Aditya J.P., Bhartiya P. \& Bhartiya A. 2011.Genetic variability, heritability and character association for yield and component characters in soybean (Glycine $\max$ (L.) Merrill). Journal of Central European Agriculture.12:27-34.

Amare Abebe and Haile Kefene, 1989. Country reports Eastern Africa. Ethiopia. p. 110- 111. In: proceedings of a workshop on bean varietal improvement in Africa.

CSA, 2017/18. Agricultural samples survey. 2017/18. Report on Area and Production of Crops, Central Statistics Authority, Addis Ababa, Ethiopia.

Dupare B.D ;Billore S.D; Joshi;Husain S.M. Origin ,domestication, introduction, and Success of soybean in India. Asian agri history vol12 no3.2008

FAO, 2017. FAOSTAT database: Agricultural crops. The Food and Agriculture Organization of the United Nations, USA.

Graham, P.H. \& Vance, C.P. 2003. Legumes: importance and constraints to greater use. Plant Physiology, 131: $872-877$.

Hammer,O and L.G.Haraldson.1975. Soybean production, protection and utilization Ethiopia.. In Hammer,O and L.G.Haraldson (Eds). proceeding conference, Addis Ababa Ethiopia.

Kumudini, S., Pallikonda, P. and Steele, C. 2007. Photoperiod and E-genes directly influence the duration of soybean reproductive development. Crop Science 47, 1510-1517.

Office of Global Analysis, Foreign Agricultural Service/United Sates Department of Agriculture, Oilseeds .2017. World Markets and Trade, USDA, Washington, D.C., USA.

Shankar k. 2014. Genetic diversity studies in soybean [glycine max (1.) Merrill] for various seed \& yield contributing characters. Ph.D. Thesis acharya ngranga agricultural university rajendranagar, hyderabad) $127 \mathrm{pp}$.

Singh M. \& Ceccarelli S. 1996. Estimation of heritability of crop traits from variety trial data. ICARDA.

Singh, P., Kumar, R., Sabapathy, S.N. \& Bawa, A.S. 2008. Functional and edible uses of soy protein products. Reviews in Food Science and Food Safety, 7: 14-28.

Waymark, D. 1997. The soybean: The golden crop of the future. Agricultural Review, 4: 37-39 